This is a self-archived version of an original article. This version may differ from the original in pagination and typographic details.

Author(s): Zhu, Qihao; Fettinger, James C.; Vasko, Petra; Power, Philip P.

Title: Interactions of a Diplumbyne with Dinuclear Transition Metal Carbonyls to Afford Metalloplumbylenes

Year: 2020

Version: Accepted version (Final draft)

Copyright: ㄷ 2020 American Chemical Society

Rights: In Copyright

Rights url: http://rightsstatements.org/page//nC/1.0/?language=en

Please cite the original version:

Zhu, Q., Fettinger, J. C., Vasko, P., \& Power, P. P. (2020). Interactions of a Diplumbyne with Dinuclear Transition Metal Carbonyls to Afford Metalloplumbylenes. Organometallics, 39(24), 4629-4636. https://doi.org/10.1021/acs.organomet.0c00659 


\title{
Interactions of a Diplumbyne with Dinuclear Transition Metal Carbonyls to Afford Metalloplumbylenes
}

Qihao Zhu, Petra Vasko, James C. Fettinger, and Philip P. Power*

\begin{abstract}
:
The metathesis reactions of the diplumbyne $\operatorname{Ar}^{\mathrm{iPr} 6} \mathrm{PbPb}^{\mathrm{i}}{ }^{\mathrm{Pr} 6}\left(\mathrm{Ar}{ }^{\mathrm{iPr} 6}=-\mathrm{C}_{6} \mathrm{H}_{3}-2,6-\left(\mathrm{C}_{6} \mathrm{H}_{2}-\right.\right.$ 2,4,6-i $\left.\left.{ }^{i} \mathrm{Pr}_{3}\right)_{2}\right)$ with the dinuclear metal carbonyls $\mathrm{Mn}_{2}(\mathrm{CO})_{10}, \mathrm{Fe}_{2}(\mathrm{CO})_{9}, \mathrm{Co}_{2}(\mathrm{CO})_{8}$ under mild conditions afforded the complexes $\mathrm{Mn}(\mathrm{CO})_{5}\left(\mathrm{PbAr}^{\mathrm{iPr} 6}\right)(\mathbf{1}), \mathrm{Fe}(\mathrm{CO})_{4}\left(\mathrm{PbAr}^{\mathrm{iPr} 6}\right)_{2}(\mathbf{2})$, $\mathrm{Co}_{4}(\mathrm{CO})_{9}\left(\mathrm{PbAr}^{\mathrm{iPr} 6}\right)_{2}(\mathbf{3})$, respectively. Complexes $\mathbf{1 - 3}$ were structurally characterized by single-crystal X-ray diffraction, and by ${ }^{1} \mathrm{H},{ }^{13} \mathrm{C}\left\{{ }^{1} \mathrm{H}\right\},{ }^{59} \mathrm{Co}\left\{{ }^{1} \mathrm{H}\right\}$, and ${ }^{207} \mathrm{~Pb}\left\{{ }^{1} \mathrm{H}\right\} \mathrm{NMR}$, UV-Vis, and IR spectroscopy. They are rare examples of species formed by the direct reaction of a group 14 dimetallyne with transition metal carbonyls. Complexes $\mathbf{1}$ and $\mathbf{2}$ feature $\mathrm{Mn}-\mathrm{Pb}$ or $\mathrm{Fe}-\mathrm{Pb}$ single bonds whereas in 3 a $\mathrm{Co}-\mathrm{Pb}$ cluster is formed in which the plumbylidyne moiety bridges either an edge or a face of $\mathrm{a} \mathrm{Co}_{4}$ carbonyl cluster.
\end{abstract}

\section{Introduction}

Organometallic complexes containing bonds between transition metals and low oxidation state group 14 element moieties are of interest because of their potential for a diverse reactivity thus arises mainly from the unsaturated character of the group 14 element bound directly to the transition metal. ${ }^{1}$ For the heavier group 14 elements, early work by Marks $^{2}$ and Lappert ${ }^{3}$ reported the synthesis of the first stannylene-transition metal complexes which were characterized spectroscopically ${ }^{2-3}$ and structurally. ${ }^{3}$ These initial examples have been followed by numerous other $\mathrm{L}_{n} \mathrm{MER}_{2}(\mathrm{~L}=$ ligand; $\mathrm{M}=$ transition metal; $\mathrm{E}=$ heavier group 14 element; $\mathrm{R}=$ organic \& related substituents) 
complexes that have incorporated the other heavier group 14 elements and various transition metals. ${ }^{4-6}$ Related to these complexes are species of formula $L_{n} M-E R$ in which the transition metal is $\sigma$-bonded directly to the group 14 element. The first such complex, Mes ${ }^{*} \mathrm{GeFe}(\mathrm{CO})_{2} \mathrm{R}\left(\mathrm{Mes}^{*}=\right.$ supermesityl, i.e. $\left.\mathrm{C}_{6} \mathrm{H}_{2}-2,4,6-{ }^{t} \mathrm{Bu}_{3} ; \mathrm{R}=\mathrm{Cp} / \mathrm{Cp} *\right)$, which was reported by Jutzi and Leue in 1994, was characterized spectroscopically. ${ }^{7}$ Later Power and coworkers reported the synthesis of metallostannylene ${ }^{8}$, $\mathrm{Cp}(\mathrm{CO})_{3} \mathrm{MSnAr}^{\mathrm{Me} 6}$, and metalloplumbylene ${ }^{9}, \mathrm{Cp}(\mathrm{CO})_{3} \mathrm{MSnAr}^{\mathrm{iPr} 6}(\mathrm{M}=\mathrm{Cr}$, Mo, or W; $\left.\mathrm{Ar}^{\mathrm{Me} 6}=-\mathrm{C}_{6} \mathrm{H}_{3}-2,6-\left(\mathrm{C}_{6} \mathrm{H}_{2}-2,4,6-\mathrm{Me}_{3}\right)_{2} ; \quad \mathrm{Ar}^{\mathrm{iPr} 6}=-\mathrm{C}_{6} \mathrm{H}_{3}-2,6-\left(\mathrm{C}_{6} \mathrm{H}_{2}-2,4,6-{ }^{i} \mathrm{Pr}_{3}\right)_{2}\right)$, analogues, and related species ${ }^{10}$. Attempts to generate the corresponding metallogermylenes led to the fortuitous discovery of a metallogermylyne featuring a molybdenum-germanium triple bond ${ }^{11}$ via carbon monoxide elimination (Scheme 1). In contrast, the corresponding chemistry with the chromium or tungsten species afforded several examples of the desired singly bonded metallogermylenes. ${ }^{12}$ Work by Filippou and coworkers disclosed other routes to the metallogermylynes ${ }^{13}$ and metallogermylenes (Scheme 1) and expanded their results to include the corresponding complexes with triple bonds to $\operatorname{tin}^{14}$ and lead. ${ }^{15}$

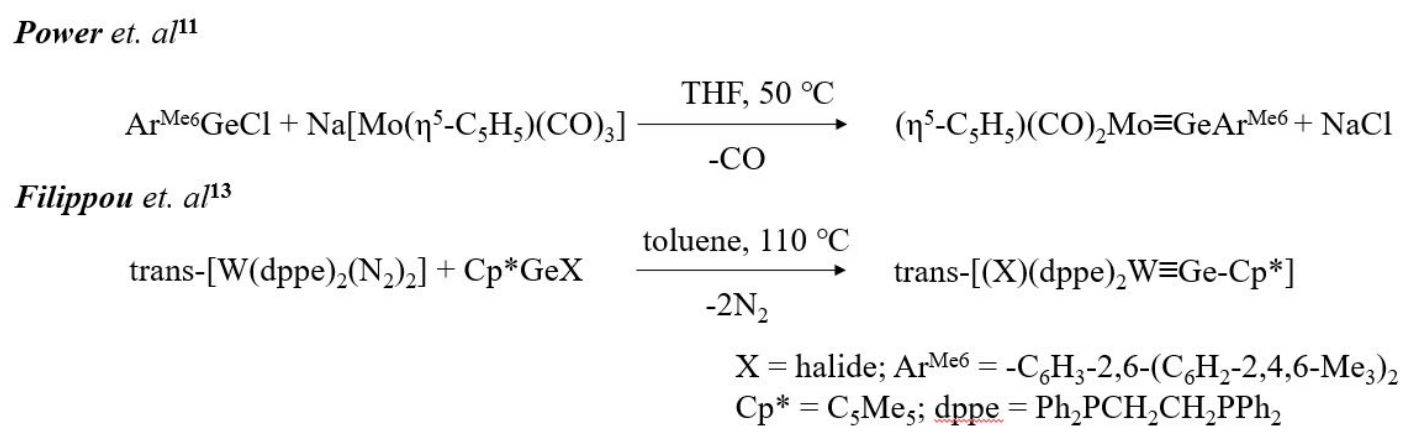

Scheme 1. Synthetic routes to metallogermylynes.

More recent work ${ }^{16}$ has shown that the above species can be synthesized by metathesis 
of the dimetallynes REER $\left(\mathrm{R}=\right.$ terphenyl; $\mathrm{E}=\mathrm{Ge},{ }^{17} \mathrm{Sn},{ }^{18}$ or $\left.\mathrm{Pb}^{19}\right)$ with the single or triple bonded transition metal species, $(\mathrm{CO})_{3} \mathrm{CpMo-MoCp}(\mathrm{CO})_{3}$ or $(\mathrm{CO})_{2} \mathrm{CpMo} \equiv \mathrm{MoCp}(\mathrm{CO})_{2} .{ }^{16}$ In addition, the distannyne and digermyne were reacted with the group 6 carbonyls $\mathrm{M}(\mathrm{CO})_{6}$ to form the cluster species, $\left\{\mathrm{Ar}^{\mathrm{iPr} 4} \mathrm{EM}(\mathrm{CO})_{4}\right\}_{2}(\mathrm{E}=$ $\left.\mathrm{Ge}, \mathrm{Sn} ; \mathrm{Ar}^{\mathrm{iPr} 4}=-\mathrm{C}_{6} \mathrm{H}_{3}-2,6-\left(\mathrm{C}_{6} \mathrm{H}_{3}-2,6-\mathrm{Pr}_{3}\right)_{2}\right) .{ }^{20}$ However, the reactivity of diplumbynes towards simple transition metal carbonyls remains hardly explored. Herein, we report the syntheses and characterizations of metalloplumbylenes $\mathrm{Mn}(\mathrm{CO})_{5}\left(\mathrm{PbAr}^{\mathrm{iPr} 6}\right)(\mathbf{1})$, $\mathrm{Fe}(\mathrm{CO})_{4}\left(\mathrm{PbAr}^{\mathrm{iPr} 6}\right)_{2}(2), \mathrm{Co}_{4}(\mathrm{CO})_{9}\left(\mathrm{PbAr}^{\mathrm{iPr} 6}\right)_{2}$ (3) by reactions of the diplumbyne, $\mathrm{Ar}^{\mathrm{iPr} 6 \mathrm{PbPbAr}}{ }^{\mathrm{iPr} 6}$, with the dinuclear metal carbonyls, $\mathrm{Mn}_{2}(\mathrm{CO})_{10}, \mathrm{Fe}_{2}(\mathrm{CO})_{9}, \mathrm{Co}_{2}(\mathrm{CO})_{8}$.

\section{Experimental Section}

General Procedures. All operations were carried out by using modified Schlenk techniques or in a Vacuum Atmospheres OMNI-Lab drybox under an atmosphere of dry argon or nitrogen. The lead compounds were manipulated with careful exclusion of light due to the tendency of low-valent lead compounds to decompose or disproportionate under illumination. Solvents were dried over an alumina column and degassed prior to use. ${ }^{21}$ The compound $\mathrm{Ar}^{\mathrm{iPr} 6} \mathrm{PbPbAr}{ }^{\mathrm{iPr} 6}$ was prepared according to literature procedures. ${ }^{19,}{ }^{22}$ Metal carbonyls were used as purchased without further purification. $\mathrm{Na}\left[\mathrm{Mn}(\mathrm{CO})_{5}\right]$ was prepared by a modified literature procedure (see $\left.\mathrm{SI}\right) .{ }^{23-}$ ${ }^{25}$ The ${ }^{1} \mathrm{H},{ }^{13} \mathrm{C}\left\{{ }^{1} \mathrm{H}\right\},{ }^{59} \mathrm{Co}\left\{{ }^{1} \mathrm{H}\right\}$, and ${ }^{207} \mathrm{~Pb}\left\{{ }^{1} \mathrm{H}\right\}$ NMR spectra were recorded on a Varian Inova $600 \mathrm{MHz}$ spectrometer. The ${ }^{1} \mathrm{H}$ and ${ }^{13} \mathrm{C}\left\{{ }^{1} \mathrm{H}\right\} \mathrm{NMR}$ spectra were referenced to the residual solvent signals in $\mathrm{C}_{6} \mathrm{D}_{6}$. The ${ }^{59} \mathrm{Co}\left\{{ }^{1} \mathrm{H}\right\}$ NMR spectrum was referenced to an 
external standard of a saturated solution of $\mathrm{K}_{3} \mathrm{Co}(\mathrm{CN})_{6}(\delta 0.0 \mathrm{ppm})$ in $\mathrm{D}_{2} \mathrm{O}$. The ${ }^{207} \mathrm{~Pb}\left\{{ }^{1} \mathrm{H}\right\}$ NMR spectra were referenced to an external standard of $\mathrm{PbMe}_{4}(\delta 0.0 \mathrm{ppm})$ in $\mathrm{CDCl}_{3}$. UV-Visible spectra were recorded in dilute hexane solutions in $3.5 \mathrm{~mL}$ quartz cuvettes using an Olis 17 Modernized Cary 14 UV-Vis/NIR spectrophotometer. Infrared spectra were collected on a Bruker Tensor 27 ATR-FTIR spectrometer.

$\operatorname{Mn}(\mathbf{C O})_{5}\left(\mathbf{P b A r}{ }^{\mathrm{iPr}}\right)$ (1). Method A: ca. $50 \mathrm{~mL}$ of THF were added to a heavy-walled Teflon tapped Schlenk flask charged with $0.395 \mathrm{~g}(0.29 \mathrm{mmol}) \mathrm{Ar}^{\mathrm{iPr} \operatorname{PbPbAr}{ }^{\mathrm{Pr} 6} \text { and }}$ $0.122 \mathrm{~g}(0.31 \mathrm{mmol}) \mathrm{Mn}_{2}(\mathrm{CO})_{10}$. The flask was then sealed, and the solution was stirred at ambient temperature for 2 days, and then heated to ca. $50{ }^{\circ} \mathrm{C}$ for 5 days, during which time the color changed from dark brown to dark green. The solution was cooled to room temperature, and filtered. The solution was then concentrated under reduced pressure to ca. $10 \mathrm{~mL}$, and cooled to a ca. $-18{ }^{\circ} \mathrm{C}$ for one week to afford the product as teal crystals of $\mathrm{Mn}(\mathrm{CO})_{5}\left(\mathrm{PbAr}^{\mathrm{Pr} 6}\right)$ (1). Yield: $0.098 \mathrm{~g}, 19 \%$.

Method B: $0.46 \mathrm{~g}(2.11 \mathrm{mmol}) \mathrm{Na}\left[\mathrm{Mn}(\mathrm{CO})_{5}\right]$ in ca. $40 \mathrm{~mL} \mathrm{Et}_{2} \mathrm{O}$ solution was added dropwise over 15 minutes to a Schlenk flask charged with $1.472 \mathrm{~g}(0.96 \mathrm{mmol})$ $\left[\mathrm{Ar}{ }^{\mathrm{iPr} 6} \mathrm{~Pb}(\mu-\mathrm{Br})\right]_{2}$ and ca. $30 \mathrm{~mL}$ of $\mathrm{Et}_{2} \mathrm{O}$ at $0{ }^{\circ} \mathrm{C}$, After stirring for 2 days, during which time the color changed from yellow to teal, solvent was removed and the residue was extracted with hexanes, and filtered. The hexanes were removed under reduced pressure and ca. $20 \mathrm{~mL}_{\text {of }} \mathrm{Et}_{2} \mathrm{O}$ was added. Storage of the solution at room temperature overnight afforded teal crystals of $\mathrm{Mn}(\mathrm{CO})_{5}\left(\mathrm{PbAr}^{\mathrm{iPr} 6}\right)$ (1) that were suitable for X-ray diffraction studies. Yield: $1.392 \mathrm{~g}, 82 \% .{ }^{1} \mathrm{H}$ NMR (600 MHz, $\left.\mathrm{C}_{6} \mathrm{D}_{6}, 298 \mathrm{~K}, \mathrm{ppm}\right): \delta=1.09$ (br, 
$\left.12 \mathrm{H}, \mathrm{p}-\mathrm{CH}\left(\mathrm{CH}_{3}\right)_{2}\right), 1.19\left(\mathrm{~d}, 12 \mathrm{H}, \mathrm{o}-\mathrm{CH}\left(\mathrm{CH}_{3}\right)_{2}\right),{ }^{3} \mathrm{~J}_{\mathrm{H}, \mathrm{H}}=6.6 \mathrm{~Hz}, 1.38(\mathrm{~d}, 12 \mathrm{H}, \mathrm{o}-$ $\left.\mathrm{CH}\left(\mathrm{CH}_{3}\right)_{2}\right),{ }^{3} \mathrm{~J}_{\mathrm{H}, \mathrm{H}}=6.6 \mathrm{~Hz}, 2.77$ (sept, $\left.2 \mathrm{H}, \mathrm{p}-\mathrm{CH}\left(\mathrm{CH}_{3}\right)_{2}\right),{ }^{3} \mathrm{~J}_{\mathrm{H}, \mathrm{H}}=7.2 \mathrm{~Hz}, 3.40(\mathrm{br}, 4 \mathrm{H}$, $\left.\mathrm{o}-\mathrm{CH}\left(\mathrm{CH}_{3}\right)_{2}\right){ }^{3} \mathrm{~J}_{\mathrm{H}, \mathrm{H}}=5.8 \mathrm{~Hz} ; 7.12$ (br, 4H, m-Trip); $7.55\left(\mathrm{t}, 1 \mathrm{H}, \mathrm{p}-\mathrm{C}_{6} \mathrm{H}_{3}\right){ }^{3} \mathrm{~J}_{\mathrm{H}, \mathrm{H}}=7.3 \mathrm{~Hz}$, $8.03\left(\mathrm{~d}, 2 \mathrm{H}, \mathrm{m}-\mathrm{C}_{6} \mathrm{H}_{3}\right){ }^{3} \mathrm{~J}_{\mathrm{H}, \mathrm{H}}=7.3 \mathrm{~Hz} .{ }^{13} \mathrm{C}\left\{{ }^{1} \mathrm{H}\right\} \mathrm{NMR}\left(151 \mathrm{MHz}, \mathrm{C}_{6} \mathrm{D}_{6}, 298 \mathrm{~K}, \mathrm{ppm}\right): \delta=$ $23.54\left(\mathrm{o}-\mathrm{CH}\left(\mathrm{CH}_{3}\right)_{2}\right), 23.95\left(\mathrm{o}-\mathrm{CH}\left(\mathrm{CH}_{3}\right)_{2}\right), 27.44\left(\mathrm{p}-\mathrm{CH}\left(\mathrm{CH}_{3}\right)_{2}\right), 30.90\left(\mathrm{o}-\mathrm{CH}\left(\mathrm{CH}_{3}\right)_{2}\right)$, $34.78\left(\mathrm{p}-\mathrm{CH}\left(\mathrm{CH}_{3}\right)_{2}\right), 122.49$ (br, m-Trip), $125.30\left(\mathrm{p}-\mathrm{C}_{6} \mathrm{H}_{3}\right), 128.30\left(\mathrm{~m}-\mathrm{C}_{6} \mathrm{H}_{3}\right), 133.02$ (i-Trip), 140.54 (p-Trip), 146.38 (o-Trip), 149.17 (o- $\left.\mathrm{C}_{6} \mathrm{H}_{3}\right), 210.94$ (br, CO), 282.93 (br, CO). ${ }^{207} \mathrm{~Pb}\left\{{ }^{1} \mathrm{H}\right\}$ NMR $\left(125 \mathrm{MHz}, \mathrm{C}_{6} \mathrm{D}_{6}, 298 \mathrm{~K}, \mathrm{ppm}\right): \delta=8007.2$. ATR-FTIR: $\boldsymbol{v}_{\mathrm{CO}}\left(\mathrm{cm}^{-1}\right)$ : 1958(s), 2060(m). UV-vis (hexane) $\lambda_{\max }=\mathrm{nm}\left(\varepsilon=\mathrm{M}^{-1} \cdot \mathrm{cm}^{-1}\right): 332(13700), 671(1640)$. $\mathbf{F e}(\mathrm{CO})_{4}\left(\mathrm{PbAr}^{\mathrm{iPr} 6}\right)_{2}(2)$. ca. $50 \mathrm{~mL}$ of $\mathrm{Et}_{2} \mathrm{O}$ was added to a Schlenk flask charged with $0.452 \mathrm{~g}(0.33 \mathrm{mmol}) \mathrm{Ar}^{\mathrm{iPr} P \mathrm{PbPbAr}}{ }^{\mathrm{iPr} 6}$ and $0.132 \mathrm{~g}(0.36 \mathrm{mmol}) \mathrm{Fe}_{2}(\mathrm{CO})_{9}$. The solution was stirred for 2 days, during which time the color changed from dark brown to green. The solution was filtered, concentrated under reduced pressure to ca. $10 \mathrm{~mL}$, and cooled to ca. $-18^{\circ} \mathrm{C}$ for one week to afford crystals of $\mathrm{Fe}(\mathrm{CO})_{4}\left(\mathrm{PbAr}{ }^{\mathrm{iPr} 6}\right)_{2}(2)$ as green needles that were suitable for X-ray diffraction studies. Yield: $0.295 \mathrm{~g}, 58 \%$. ${ }^{1} \mathrm{H}$ NMR (600 $\left.\mathrm{MHz}, \mathrm{C}_{6} \mathrm{D}_{6}, 298 \mathrm{~K}, \mathrm{ppm}\right): \delta=1.13\left(\mathrm{~d}, 12 \mathrm{H}, \mathrm{p}-\mathrm{CH}\left(\mathrm{CH}_{3}\right)_{2}\right),{ }^{3} \mathrm{~J}_{\mathrm{H}, \mathrm{H}}=5.5 \mathrm{~Hz} .1 .28(\mathrm{~d}, 12 \mathrm{H}$, $\left.\mathrm{o}-\mathrm{CH}\left(\mathrm{CH}_{3}\right)_{2}\right),{ }^{3} \mathrm{~J}_{\mathrm{H}, \mathrm{H}}=6.2 \mathrm{~Hz}, 1.36\left(\mathrm{~d}, 12 \mathrm{H}, \mathrm{o}-\mathrm{CH}\left(\mathrm{CH}_{3}\right)_{2}\right),{ }^{3} \mathrm{~J}_{\mathrm{H}, \mathrm{H}}=7.0 \mathrm{~Hz}, 2.85(\mathrm{sept}, 2 \mathrm{H}$, p-CH( $\left.\left(\mathrm{CH}_{3}\right)_{2}\right),{ }^{3} \mathrm{~J}_{\mathrm{H}, \mathrm{H}}=6.6 \mathrm{~Hz}, 3.46\left(\operatorname{broad}, 4 \mathrm{H}, \mathrm{o}-\mathrm{CH}\left(\mathrm{CH}_{3}\right)_{2}\right){ }^{3} \mathrm{~J}_{\mathrm{H}, \mathrm{H}}=5.8 \mathrm{~Hz} ; 7.12(\mathrm{~s}, 4 \mathrm{H}$, m-Trip); $7.51\left(\mathrm{t}, 1 \mathrm{H}, \mathrm{p}-\mathrm{C}_{6} \mathrm{H}_{3}\right){ }^{3} \mathrm{~J}_{\mathrm{H}, \mathrm{H}}=7.1 \mathrm{~Hz}, 8.06\left(\mathrm{~d}, 2 \mathrm{H}, \mathrm{m}-\mathrm{C}_{6} \mathrm{H}_{3}\right){ }^{3} \mathrm{~J}_{\mathrm{H}, \mathrm{H}}=7.9 \mathrm{~Hz}$. ${ }^{13} \mathrm{C}\left\{{ }^{1} \mathrm{H}\right\}$ NMR $\left(151 \mathrm{MHz}, \mathrm{C}_{6} \mathrm{D}_{6}, 298 \mathrm{~K}, \mathrm{ppm}\right): \delta=23.46\left(\mathrm{o}-\mathrm{CH}\left(\mathrm{CH}_{3}\right)_{2}\right), 24.24$ (o$\left.\mathrm{CH}\left(\mathrm{CH}_{3}\right)_{2}\right), 27.14\left(\mathrm{p}-\mathrm{CH}\left(\mathrm{CH}_{3}\right)_{2}\right), 30.66\left(\mathrm{o}-\mathrm{CH}\left(\mathrm{CH}_{3}\right)_{2}\right), 34.73\left(\mathrm{p}-\mathrm{CH}\left(\mathrm{CH}_{3}\right)_{2}\right), 120.73$ (m-Trip), $124.99\left(\mathrm{p}-\mathrm{C}_{6} \mathrm{H}_{3}\right), 128.29\left(\mathrm{~m}_{-} \mathrm{C}_{6} \mathrm{H}_{3}\right), 133.60$ (i-Trip), 141.21 (p-Trip), 145.95 
(o-Trip), 149.00 (o- $\left.\mathrm{C}_{6} \mathrm{H}_{3}\right), 295.48$ (br, CO). ${ }^{207} \mathrm{~Pb}\left\{{ }^{1} \mathrm{H}\right\}$ NMR (125 MHz, $\mathrm{C}_{6} \mathrm{D}_{6}, 298 \mathrm{~K}$, ppm): not observed. ATR-FTIR: $\boldsymbol{v}_{\mathrm{CO}}\left(\mathrm{cm}^{-1}\right)$ : 1889(m), 1958(m), 2005(m), 2041(w). UV-vis (hexane) $\lambda_{\max }=\mathrm{nm}\left(\varepsilon=\mathrm{M}^{-1 \cdot} \mathrm{cm}^{-1}\right): 341$ (22700), 505 (3140), 641 (3000).

$\mathrm{Co}_{4}(\mathbf{C O})_{9}\left(\mathrm{PbAr}^{\mathrm{iPr} 6}\right)_{2}(3)$. ca. $50 \mathrm{~mL}$ of hexane was added to a Schlenk flask charged with $0.330 \mathrm{~g}(0.24 \mathrm{mmol}) \mathrm{Ar}^{\mathrm{iPr} 6 \mathrm{PbPbAr}}{ }^{\mathrm{Pr} 6}$ and $0.168 \mathrm{~g}(0.49 \mathrm{mmol}) \mathrm{Co}_{2}(\mathrm{CO})_{8}$. After stirring overnight, during which time the color changed from dark brown to dark red, the solution was filtered, concentrated under reduced pressure to ca. $15 \mathrm{~mL}$, and cooled to ca. $-30{ }^{\circ} \mathrm{C}$ for one week to afford crystals of $\mathrm{Co}_{4}(\mathrm{CO})_{9}\left(\mathrm{PbAr}^{\mathrm{iPr} 6}\right)_{2}(\mathbf{3})$ as dark maroon blocks that were suitable for X-ray diffraction studies. Yield: $0.299 \mathrm{~g}, 67 \%$ \% ${ }^{1} \mathrm{H}$ NMR $\left(600 \mathrm{MHz}, \mathrm{C}_{6} \mathrm{D}_{6}, 298 \mathrm{~K}, \mathrm{ppm}\right): \delta=1.11\left(\mathrm{~d}, 12 \mathrm{H}, \mathrm{p}-\mathrm{CH}\left(\mathrm{CH}_{3}\right)_{2}\right),{ }^{3} \mathrm{~J}_{\mathrm{H}, \mathrm{H}}=6.6 \mathrm{~Hz} .1 .38(\mathrm{~d}$, $12 \mathrm{H}$, o- $\left.\mathrm{CH}\left(\mathrm{CH}_{3}\right)_{2}\right),{ }^{3} \mathrm{~J}_{\mathrm{H}, \mathrm{H}}=6.9 \mathrm{~Hz}, 1.56\left(\mathrm{~d}, 12 \mathrm{H}, \mathrm{o}-\mathrm{CH}\left(\mathrm{CH}_{3}\right)_{2}\right),{ }^{3} \mathrm{~J}_{\mathrm{H}, \mathrm{H}}=6.9 \mathrm{~Hz}, 2.92$ (sept, $\left.2 \mathrm{H}, \mathrm{p}-\mathrm{CH}\left(\mathrm{CH}_{3}\right)_{2}\right),{ }^{3} \mathrm{~J}_{\mathrm{H}, \mathrm{H}}=7.1 \mathrm{~Hz}, 3.16\left(\right.$ broad, $\left.4 \mathrm{H}, \mathrm{o}-\mathrm{CH}\left(\mathrm{CH}_{3}\right)_{2}\right){ }^{3} \mathrm{~J}_{\mathrm{H}, \mathrm{H}}=7.4 \mathrm{~Hz}$; $7.26\left(\mathrm{~s}, 4 \mathrm{H}, \mathrm{m}-\right.$ Trip); $7.38\left(\mathrm{t}, 1 \mathrm{H}, \mathrm{p}-\mathrm{C}_{6} \mathrm{H}_{3}\right){ }^{3} \mathrm{~J}_{\mathrm{H}, \mathrm{H}}=5.9 \mathrm{~Hz}, 7.88\left(\mathrm{~d}, 2 \mathrm{H}, \mathrm{m}-\mathrm{C}_{6} \mathrm{H}_{3}\right){ }^{3} \mathrm{~J}_{\mathrm{H}, \mathrm{H}}=$ 7.3 Hz. ${ }^{13} \mathrm{C}\left\{{ }^{1} \mathrm{H}\right\}$ NMR (151 MHz, $\left.\mathrm{C}_{6} \mathrm{D}_{6}, 298 \mathrm{~K}, \mathrm{ppm}\right): \delta=23.47\left(\mathrm{o}-\mathrm{CH}\left(\mathrm{CH}_{3}\right)_{2}\right), 24.05$ (o- $\left.\mathrm{CH}\left(\mathrm{CH}_{3}\right)_{2}\right), 26.14\left(\mathrm{p}-\mathrm{CH}\left(\mathrm{CH}_{3}\right)_{2}\right), 31.08\left(\mathrm{o}-\mathrm{CH}\left(\mathrm{CH}_{3}\right)_{2}\right), 34.92\left(\mathrm{p}-\mathrm{CH}\left(\mathrm{CH}_{3}\right)_{2}\right), 123.15$ (m-Trip), 128.89 (p- $\left.\mathrm{C}_{6} \mathrm{H}_{3}\right), 134.74\left(\mathrm{~m}-\mathrm{C}_{6} \mathrm{H}_{3}\right), 138.52$ (i-Trip), 143.57 (p-Trip), 146.42 (o-Trip), 149.99 (o- $\mathrm{C}_{6} \mathrm{H}_{3}$ ), 213.17 (br, CO). ${ }^{59} \mathrm{Co} \mathrm{NMR}$ (142 MHz, $\mathrm{C}_{6} \mathrm{D}_{6}, 298 \mathrm{~K}, \mathrm{ppm}$ ): $\delta=-173.0(\operatorname{Co}(1)$, relative intensity $=1),-654.4(\operatorname{Co}(2)$ and $\operatorname{Co}(3)$, relative intensity $=$ 2), $-2016.0(\mathrm{Co}(4)$, relative intensity $=1) .{ }^{207} \mathrm{~Pb}\left\{{ }^{1} \mathrm{H}\right\} \mathrm{NMR}\left(125 \mathrm{MHz}, \mathrm{C}_{6} \mathrm{D}_{6}, 298 \mathrm{~K}\right.$, ppm): $\delta=9010.4$ ATR-FTIR: $\boldsymbol{v}_{\mathrm{CO}}\left(\mathrm{cm}^{-1}\right): 1820(\mathrm{~m}), 1849(\mathrm{~m}), 1948(\mathrm{~m}), 1972(\mathrm{~s})$, 2008(m), 2035(m). UV-vis (hexane) $\lambda_{\max }=\mathrm{nm}\left(\varepsilon=\mathrm{M}^{-1} \cdot \mathrm{cm}^{-1}\right): 368$ (shoulder, 57700). 


\section{Results and Discussion}

Synthesis. Metathetical exchange between group 14 dimetallynes, $\mathrm{Ar}^{\mathrm{iPr} 4} \mathrm{MMAr}^{\mathrm{iPr} 4}$ or $\operatorname{Ar}^{\mathrm{iPr} 6} \mathrm{MMAr}^{\mathrm{iPr} 6} \quad(\mathrm{M}=\mathrm{Ge}, \quad \mathrm{Sn}, \quad$ or $\mathrm{Pb})$ and $(\mathrm{CO})_{3} \mathrm{CpMo}-\mathrm{MoCp}(\mathrm{CO})_{3}$ or $(\mathrm{CO})_{2} \mathrm{CpMo} \equiv \mathrm{MoCp}(\mathrm{CO})_{2}$, was shown earlier to afford the complexes, $\mathrm{Ar}^{\mathrm{iPr} 4} \mathrm{M} \equiv \mathrm{MoCp}(\mathrm{CO})_{2}, \quad \mathrm{Ar}^{\mathrm{iPr} 6} \mathrm{M} \equiv \mathrm{MoCp}(\mathrm{CO})_{2}, \quad$ and $\mathrm{Ar}^{\mathrm{iPr} 4} \mathrm{M}-\mathrm{MoCp}(\mathrm{CO})_{3}$ or $\operatorname{Ar}^{\mathrm{iPr} 6 \mathrm{M}-}$ $\mathrm{MoCp}(\mathrm{CO})_{3} \cdot{ }^{16}$ In particular, the relatively weak $\mathrm{Pb}-\mathrm{Pb}$ bond of the diplumbyne ${ }^{22}$ is expected to facilitate these reactions with metal-metal (M-M) bonded transition metal carbonyl dimers, hence we studied the reactions of the nominally M-M bonded dinuclear metal carbonyls $\mathrm{Mn}_{2}(\mathrm{CO})_{10}, \mathrm{Fe}_{2}(\mathrm{CO})_{9}, \mathrm{Co}_{2}(\mathrm{CO})_{8}$ with the diplumbyne, $\mathrm{Ar}^{\mathrm{iPr} 6 \mathrm{PbPbAr}}{ }^{\mathrm{iPr} 6}$. Compounds $\mathrm{Mn}(\mathrm{CO})_{5}\left(\mathrm{PbAr}^{\mathrm{iPr} 6}\right) \quad$ (1), $\mathrm{Fe}(\mathrm{CO})_{4}\left(\mathrm{PbAr}^{\mathrm{iPr} 6}\right)_{2}$ $\mathrm{Co}_{4}(\mathrm{CO})_{9}\left(\mathrm{PbAr}^{\mathrm{iPr} 6}\right)_{2}(3)$ were attained by the reaction of the diplumbyne with the dinuclear metal carbonyls either in ethereal solvents $\left(\mathrm{Et}_{2} \mathrm{O}\right.$ or $\left.\mathrm{THF}\right)$ or in hexanes (Scheme 2). For compounds $\mathbf{2}$ and $\mathbf{3}$, the syntheses were carried at ambient temperature, and the products were isolated in moderate to good yields. A similar approach to the

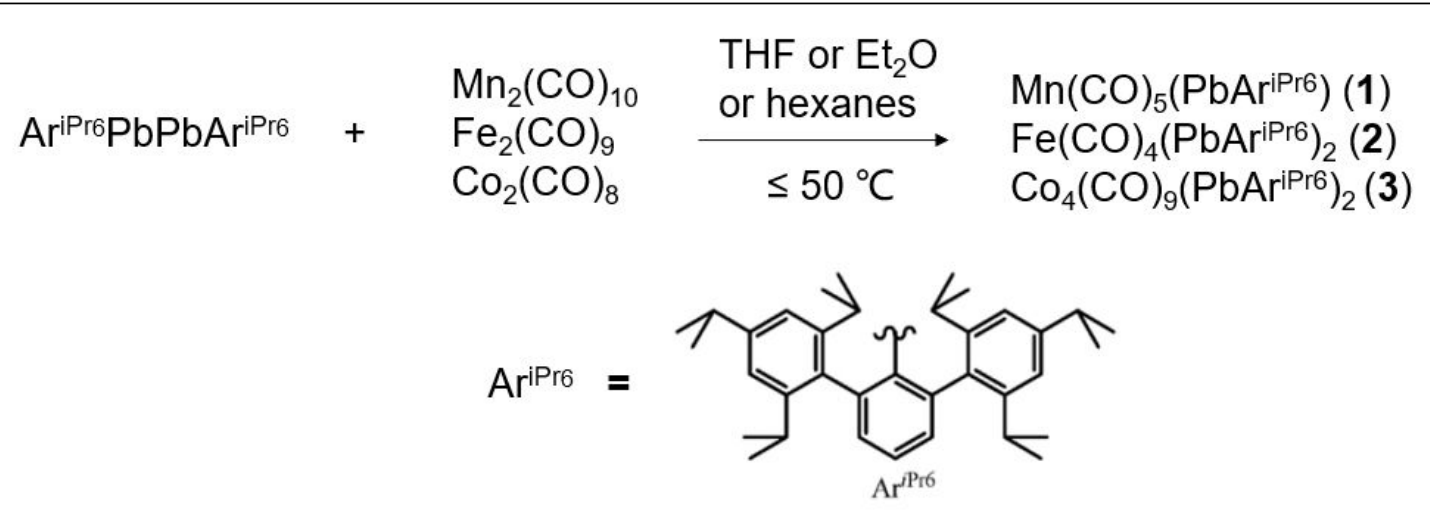

Scheme 2. Reactions of Ar ${ }^{\text {iPr6PbPbAr }}{ }^{\text {iPr6 }}$ with metal carbonyls.

synthesis of $\mathbf{1}$ afforded a color change from dark brown to green. However, the major signals in the ${ }^{1} \mathrm{H}$ NMR spectrum of the residue after removal of solvent were attributed 
to the unreacted starting materials. To avoid the propensity for decomposition of the diplumbyne under irradiation, gentle heating was applied to the reaction solution after stirring at room temperature for two days. This approach afforded 1 in low (ca. 20\%) yield. In contrast, an alternative approach to the synthesis of $\mathbf{1}$ via salt metathesis of $\left[\mathrm{Ar}{ }^{\mathrm{iPr} 6} \mathrm{~Pb}(\mu-\mathrm{Br})\right]_{2}$ and $\mathrm{Na}\left[\mathrm{Mn}(\mathrm{CO})_{5}\right]$ afforded 1 in a much higher $(82 \%)$ yield.

The synthesis of 1 by reaction of $\mathrm{Ar}^{\mathrm{iPr} 6} \mathrm{PbPbAr}{ }^{\mathrm{P} r 6}$ and $\mathrm{Mn}_{2}(\mathrm{CO})_{10}$ is formally a metathetical exchange between the $\mathrm{Pb} \equiv \mathrm{Pb}$ 'triple' bond and the $\mathrm{Mn}-\mathrm{Mn}$ single bond. However, for steric reasons it seems unlikely that this reaction proceeds via intact dinuclear metal carbonyls. In the cases of $\mathbf{1 - 3}$, it is proposed that the diplumbyne, $\mathrm{Ar}^{\mathrm{iPr} 6} \mathrm{PbPbAr}{ }^{\mathrm{iPr} 6}$, dissociates into $\mathrm{Ar}^{\mathrm{iPr} 6} \mathrm{~Pb} \cdot$ radical fragment ${ }^{16},{ }^{26}$, followed by subsequent reaction with $\mathrm{Mn}_{2}(\mathrm{CO})_{10}, \mathrm{Fe}_{2}(\mathrm{CO})_{9}$, or $\mathrm{Co}_{2}(\mathrm{CO})_{8}$.

The yields of the reactions between diplumbyne and metal carbonyls are possibly affected by the transition metal-metal (M-M) bond strength. Recently, Shaik and coworkers presented computational studies on the M-M bonds in transition metal complexes using of ab initio valence-bond methods, in which the M-M bonds of the 3d-series (group 3-10) are considered as pure charge shift bonds. ${ }^{27}$ The Mn-Mn bond in $\mathrm{Mn}_{2}(\mathrm{CO})_{10}$ is calculated to have a bond dissociation energy of $22.9 \mathrm{kcal} / \mathrm{mol}$ with a charge-shift resonance energy of $24.5 \mathrm{kcal} / \mathrm{mol}$ (experimental $38.0 \pm 5 \mathrm{kcal} / \mathrm{mol})^{28}$ suggesting that the Mn-Mn bond is the strongest $\mathrm{M}-\mathrm{M}$ bond among $\mathrm{Mn}_{2}(\mathrm{CO})_{10},{ }^{27}$ $\mathrm{Fe}_{2}(\mathrm{CO})_{9}$ (no Fe-Fe bond $),{ }^{29}$ and $\mathrm{Co}_{2}(\mathrm{CO})_{8}(9.8 \mathrm{kcal} / \mathrm{mol}),{ }^{27}$ which may account for the relatively low yield of $\mathbf{1}$ in the reaction between $\mathrm{Ar}^{\mathrm{iPr}} \mathrm{PbPbAr}^{\mathrm{Pr} 6}$ and $\mathrm{Mn}_{2}(\mathrm{CO})_{10}$. Both the teal crystals of $\mathbf{1}$, and green crystals of $\mathbf{2}$ are highly air-sensitive, and an 
immediate color change is observed upon their exposure to air. Dark maroon crystals of 3 can be briefly handled in air without displaying significant color change. Hydrocarbon solutions of $\mathbf{1}, \mathbf{2}$, and $\mathbf{3}$ were prone to decomposition by light over time, with lead metal deposition and a lightening of the color of the solution.

Structures. The solid-state molecular structures of compounds 1, 2, and $\mathbf{3}$ were determined by single crystal X-ray crystallography. Selected bond distances and bond angles are given in Table 1, and the molecular structures of $\mathbf{1 , 2}$, and $\mathbf{3}$ are illustrated in Figures 1-3, respectively.

Compound $\mathbf{1}$ crystallized in the I2/a space group. The manganese atom in compound $\mathbf{1}$ is six-coordinate with a near-octahedral coordination geometry. The $\mathrm{Pb}$ - Mn distance is 2.838(4) $\AA$, which is slightly longer than the Pb-Mn single bonds in $\left[\mathrm{Pb}\left\{\mathrm{Mn}(\mathrm{CO})_{5}\right\}_{3}\right]\left[\mathrm{AlCl}_{4}\right]^{30}(2.750(1)-2.785(1) \AA)$, and the $\mathrm{Pb}-\mathrm{Mn}$ single bond in the dimetalloborylene complex, $\left(\mathrm{Ph}_{3} \mathrm{~Pb}\right)\left[\mathrm{Mn}\left(\eta^{5}-\mathrm{C}_{5} \mathrm{H}_{5}\right)(\mathrm{CO})_{2}\right]_{2} \mathrm{~B}, 2.703(7) \AA{ }^{31}$ The $\mathrm{Pb}-\mathrm{Mn}$ bond distance in $\mathbf{1}$ is slightly shorter than the sum $(2.85 \AA)$ of the covalent radii of $\mathrm{Mn}(1.39 \AA)$ and $\mathrm{Pb}(1.46 \AA) .{ }^{32-34}$ The interligand angles at the Mn atom range from $82.65(8)^{\circ}$ to $96.75(11)^{\circ}$ which deviate somewhat $\left(<7.5^{\circ}\right)$ from the $90^{\circ}$ value expected for idealized octahedral coordination. The $\mathrm{C}(1)-\mathrm{Pb}(1)-\mathrm{Mn}(1)$ angle at the lead atom is $106.45(5)^{\circ}$ 


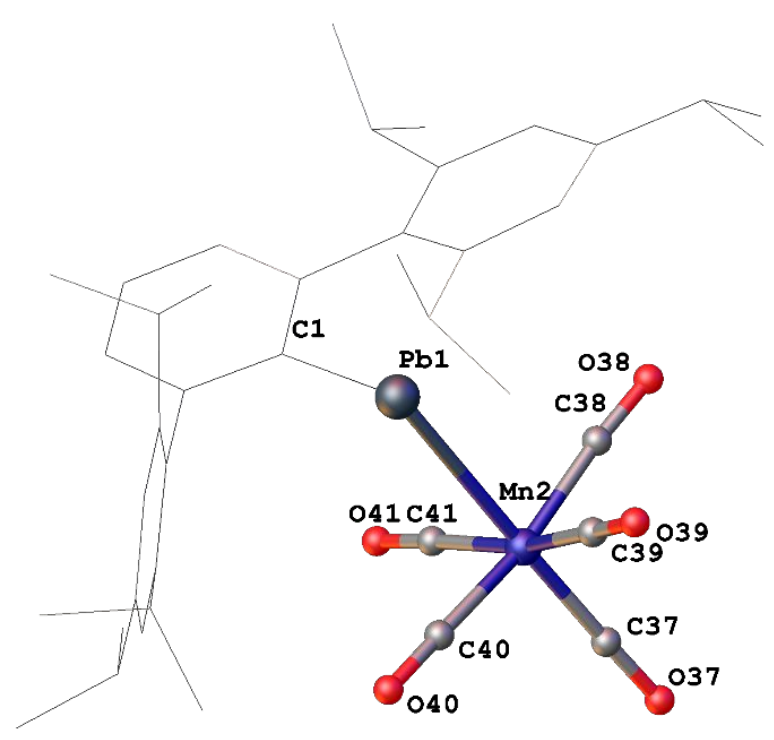

Figure 1. Thermal ellipsoid (50\%) plot of $\mathbf{1} . \mathrm{H}$ atoms and disordered groups are not shown for clarity, the organic substituents are shown as wire frames.

The molecular structure of $\mathbf{2}$ showed that it has a six-coordinated iron atom with four carbonyl ligands and two mutually cis-PbAriPr6 moieties, which afford distorted octahedral coordination at iron. The interligand angles at the iron atom range from $75.0(5)^{\circ}$ to $106.5(7)^{\circ}$. The deviation of interligand angles from ideal octahedral geometry at iron is possibly due to the steric hindrance between the two cis-PbAriPr6 moieties. The two Pb- Fe bond distances are 2.830(3) $\AA$, and 2.804(3) $\AA$, which are slightly longer than the sum $(2.78 \AA)$ of the covalent radii of $\mathrm{Pb}(1.46 \AA)$ and $\mathrm{Fe}(1.32$ $\AA$ ). ${ }^{32-34}$ The $\mathrm{Pb}-\mathrm{Fe}$ bond lengths in $\mathbf{2}$ are slightly longer than the $\mathrm{Pb}-\mathrm{Fe}$ distances, $(2.736(2) \AA$ and $2.728(2) \AA)$, observed in $\left[\mathrm{Et}_{2} \mathrm{PbFe}(\mathrm{CO})_{4}\right]_{2}$ by Wrackmeyer and coworkers. ${ }^{35}$ The relatively long Fe-Pb and $\mathrm{Mn}-\mathrm{Pb}$ distances in $\mathbf{1}$ and $\mathbf{2}$ are consistent 


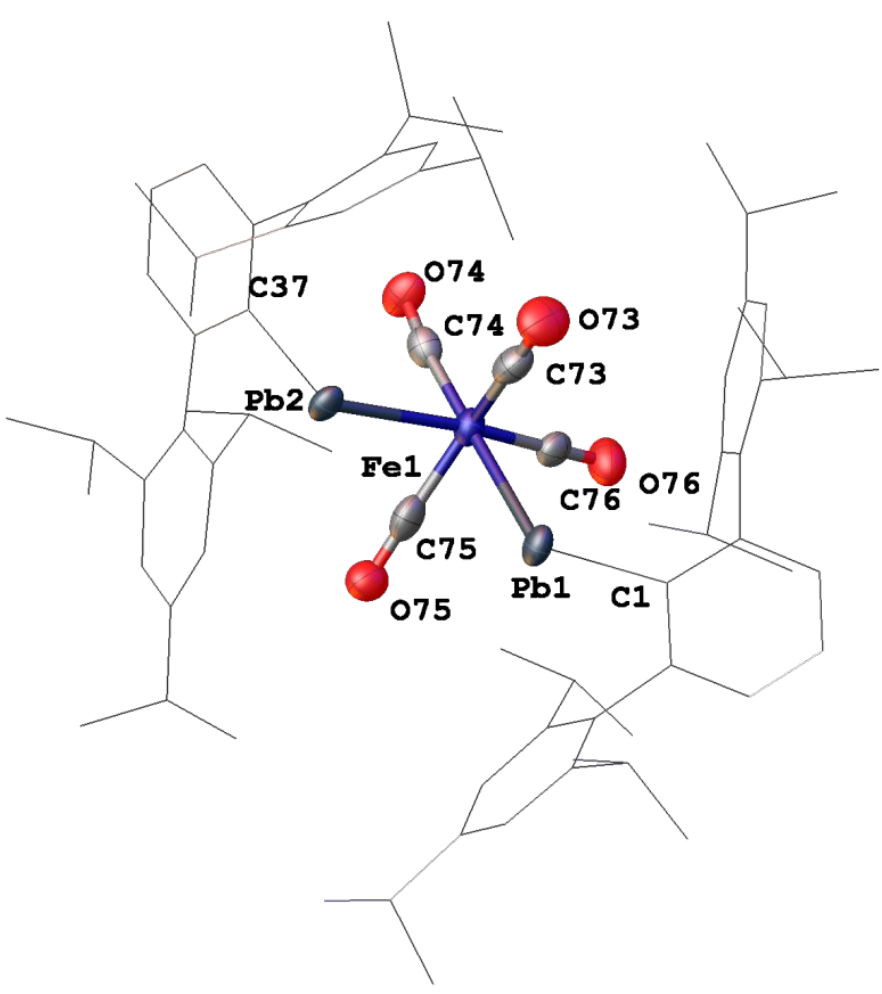

Figure 2. Thermal ellipsoid (50\%) plot of $\mathbf{2} . \mathrm{H}$ atoms and disordered groups are not shown for clarity, the organic substituents are shown as wire frames.

with $\mathrm{a}+2$ oxidation state of lead as the $\sigma$-bonds are likely to be dominated by the porbital character from the $\mathrm{Pb}(\mathrm{II})$ atom, assuming that the transition metal carbonyl fragment carries a negative charge. ${ }^{9}$ The interligand angles at the lead atom(s) of 1 $\left(106.45(5)^{\circ}\right)$ and $2\left(100.50(3)^{\circ}, 102.70(3)^{\circ}\right)$ are slightly narrower than those in the $\mathrm{Cp}(\mathrm{CO})_{3} \mathrm{M}-\mathrm{PbAr}{ }^{\mathrm{iPr} 6}(\mathrm{M}=\mathrm{Cr}, \mathrm{Mo}, \mathrm{W})$ complexes $\left(108.6(2)^{\circ}-113.58(9)^{\circ}\right)^{9}$, possibly due to the steric differences between carbonyl groups and cyclopentadienyl group. The structures of 1 and $\mathbf{2}$ can also be rationalized by the 18-electron rule where the PbAriPr6 moieties are 1-electron ligands bound to the transition metals. ${ }^{9}$

Compound 3 crystallized as dark maroon blocks in the $\mathrm{P} 2_{1} / \mathrm{c}$ space group. The molecular structure of 3 displays a near-tetrahedral $\mathrm{Co}_{4}$ core bonded to a total of nine 
carbonyls and two $\mathrm{PbAr}{ }^{\mathrm{iPr} 6}$ moieties. Seven of the carbonyls are terminally bound, with the remaining two carbonyls and one of the $\mathrm{PbAr}^{\mathrm{iPr} 6}$ moieties each bridging one of the three edges linking the apical cobalt atom with the three basal cobalt atoms. The remaining $\mathrm{PbAr}{ }^{\mathrm{iPr} 6}$ moiety bridges the face formed from the three basal cobalt atoms. The apical cobalt atom carries only one terminal carbonyl, while each of the basal cobalt atoms carry two terminal carbonyls. The structure of $\mathbf{3}$ therefore differs from that of $\mathrm{Co}_{4}(\mathrm{CO})_{12}$, where the apical atom is connected to three terminal carbonyls. The structure of compound 3 conforms to Wade's rules which predict a nido structure for the tetracobalt tetrahedron core as it has $\mathrm{n}+2$ ( $\mathrm{n}=$ no. of vertices) skeletal electron pairs

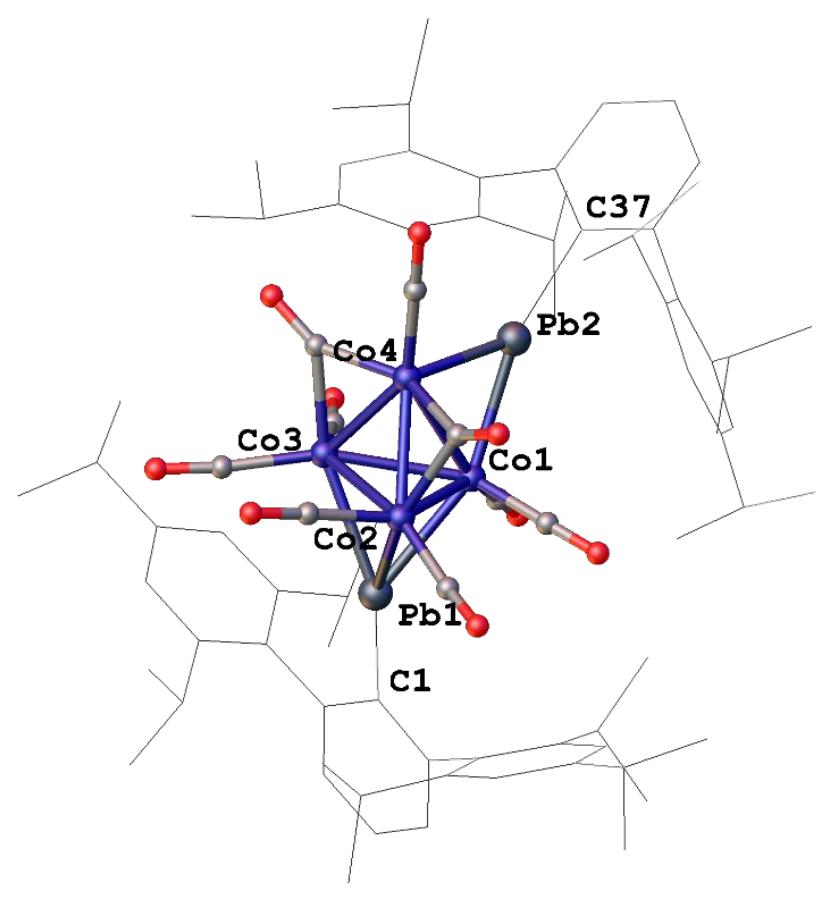

Figure 3. Thermal ellipsoid (50\%) plot of 3. H atoms and disordered groups are not shown for clarity, the organic substituents are shown as wire frames.

for cluster bonding. ${ }^{36-37}$ The edge-bridging $\mathrm{Pb}$-Co bonds are 2.5008(7) $\AA$ and 2.5150(6) $\AA$, while the average of the face-bridging Pb-Co distances is $2.5750(8) \AA$, which is 
Table 1. Selected bond distances $(\AA)$ and angles $\left(^{\circ}\right)$ for 1-3.

\begin{tabular}{|c|c|c|c|}
\hline & $\begin{array}{c}1 \\
(\mathrm{M}=\mathrm{Mn})\end{array}$ & $\begin{array}{c}2 \\
(\mathrm{M}=\mathrm{Fe})\end{array}$ & $\begin{array}{c}3 \\
(\mathrm{M}=\mathrm{Co})\end{array}$ \\
\hline $\mathrm{Pb}-\mathrm{C}$ & $2.288(2)$ & $\begin{array}{l}\mathrm{Pb}(1)-\mathrm{C}(1) 2.313(13) \\
\mathrm{Pb}(2)-\mathrm{C}(37) 2.307(13)\end{array}$ & $\begin{array}{l}\mathrm{Pb}(1)-\mathrm{C}(1) 2.229(2) \\
\mathrm{Pb}(2)-\mathrm{C}(37) 2.214(2)\end{array}$ \\
\hline $\mathrm{Pb}-\mathrm{M}$ & $2.8376(4)$ & $\begin{array}{l}\mathrm{Pb}(1)-\mathrm{Fe}(1) 2.800(2) \\
\mathrm{Pb}(2)-\mathrm{Fe}(1) 2.829(2)\end{array}$ & $\begin{array}{c}2.5078(4) \text { (average of edge- } \\
\text { bridging) } \\
2.5735(4) \text { (average of face- } \\
\text { bridging) }\end{array}$ \\
\hline M-CO (average) & $1.839(3)$ & $1.772(19)$ & $\begin{array}{l}1.775(3) \text { (terminal) } \\
1.932(3) \text { (bridging) }\end{array}$ \\
\hline \multirow[b]{2}{*}{$\mathrm{M}-\mathrm{Pb}-\mathrm{C}$} & \multirow[b]{2}{*}{$106.45(5)$} & $\begin{array}{l}\mathrm{C}(1)-\mathrm{Pb}(1)-\mathrm{Fe}(1) \\
102.70(3)\end{array}$ & $\begin{array}{c}\mathrm{C}(37)-\mathrm{Pb}(2)-\mathrm{Co}(4) 130.44(7) \\
\mathrm{C}(37)-\mathrm{Pb}(2)-\mathrm{Co}(1) 162.43(7) \\
\text { (edge-bridging) }\end{array}$ \\
\hline & & $\begin{array}{c}\mathrm{C}(37)-\mathrm{Pb}(2)-\mathrm{Fe}(1) \\
100.50(3)\end{array}$ & $\begin{array}{c}\mathrm{C}(1)-\mathrm{Pb}(1)-\mathrm{Co}(1) 128.18(6) \\
\mathrm{C}(1)-\mathrm{Pb}(1)-\mathrm{Co}(2) 153.22(6) \\
\mathrm{C}(1)-\mathrm{Pb}(1)-\mathrm{Co}(3) 146.90(6) \\
\text { (face-bridging) }\end{array}$ \\
\hline
\end{tabular}

slightly longer than the edge-bridging distance as expected for the higher coordination number. The Co-Co lengths are similar to those of the Co-Co bonds (2.441(14) $\AA$ to $2.527(10) \AA$ ) in cobalt carbonyl clusters ${ }^{38}$ except that the $\mathrm{Co}(1)-\mathrm{Co}(4)$ distance bridged by the $\mathrm{PbAr}{ }^{\mathrm{iPr} 6}$ moiety which is $2.7472(9) \AA$, much longer than an average Co-Co bond, 2.499(1) $\AA .^{39-41}$ The calculated structure of the unsaturated compound $\mathrm{Co}_{4}(\mathrm{CO})_{11}$ reported by King and coworkers ${ }^{42}$ was predicted to have a $\mu_{4}$-CO group bridging all four cobalt atoms, where the structure of $\mathbf{3}$ resembles one of the predicted structures with a butterfly array of cobalt atoms. The calculated structure indicated a long $\mathrm{Co}{ }^{\cdots} \mathrm{Co}$ distance between the two wingtips cobalt atoms of $2.974 \AA$ (B3LYP) or $3.105 \AA$ (BP86), in the $\mathrm{Co}_{4}$ butterfly, $0.2 \sim 0.3 \AA$ longer than $\mathrm{Co}(1)-\mathrm{Co}(4)$ in the structure of $3 .{ }^{42}$ The structure of $\mathbf{3}$ displays wide interligand angles at the lead atoms (see Table 1) thus arises from the bridging nature of the $\mathrm{PbAr}^{\mathrm{iPr} 6}$ moieties and the higher coordination number 
at lead atom. In addition, the sum of the angles at $\mathrm{Pb}(2)$ is $359.26(7)^{\circ}$, consistent with a planar coordination geometry. The $\mathrm{Pb}-\mathrm{C}$ distances in $\mathbf{1 - 3}$ range from $2.214(2) \AA$ to 2.313(13) $\AA$ which are within the range of reported divalent aryllead species. ${ }^{43-45}$ The transition metal-carbon distances to the carbonyl groups are comparable to their parent metal carbonyls. ${ }^{46}$

Spectroscopy. ${ }^{1} \mathrm{H}$ and ${ }^{13} \mathrm{C}\left\{{ }^{1} \mathrm{H}\right\}$ NMR spectra of $\mathbf{1}, \mathbf{2}$, and 3 indicate the high purity of the samples. The ${ }^{1} \mathrm{H}$ NMR spectra of $\mathbf{1}$ and $\mathbf{2}$ each displayed a set of signals which correspond to the ligand, AriPr6.45 Peak broadenings were observed in the ${ }^{1} \mathrm{H}$ NMR spectrum of 1 possibly due to restricted rotations of the flanking rings, which has been noted previously. ${ }^{22}$ The ${ }^{1} \mathrm{H}$ NMR spectrum of $\mathbf{3}$ displayed two sets of peaks attributable to the ligand which differ by approximately $0.01 \mathrm{ppm}$ due to the two slightly different environments of the face-bridging and edge-bridging lead atoms.

The ${ }^{13} \mathrm{C}\left\{{ }^{1} \mathrm{H}\right\}$ NMR spectra of 1, 2, and $\mathbf{3}$ displayed signals similar to those in the previously reported complexes, $\left(\eta^{5}-\mathrm{C}_{5} \mathrm{H}_{5}\right)(\mathrm{CO})_{3} \mathrm{M}-\mathrm{PbAr}^{\mathrm{iPr} 6}(\mathrm{M}=\mathrm{Cr}, \mathrm{Mo}, \mathrm{W})$, including 3 where there was only one set of signals from the ligand, $\operatorname{Ar}{ }^{\mathrm{iPr} 6}$. The ${ }^{13} \mathrm{C}\left\{{ }^{1} \mathrm{H}\right\} \mathrm{NMR}$ spectrum of $\mathbf{1}$ displayed two peaks attributable to the carbonyl groups at $210.94 \mathrm{ppm}$, and $282.93 \mathrm{ppm}$ (Table 2) in an approximate integration ratio of 4:1, which correspond to the COs cis and trans to the $\mathrm{PbAr}{ }^{\mathrm{iPr} 6}$ substituents. There is no indication of restricted rotation around the $\mathrm{Pb}(1)-\mathrm{Mn}(1)$ axis in the ${ }^{13} \mathrm{C}\left\{{ }^{1} \mathrm{H}\right\}$ NMR spectrum, consistent with a single bond between $\mathrm{Pb}$ and $\mathrm{Mn}$. The ${ }^{13} \mathrm{C}\left\{{ }^{1} \mathrm{H}\right\}$ NMR spectra of $\mathbf{2}$ and $\mathbf{3}$ each showed a single broad signal at $295.48 \mathrm{ppm}$, and $213.17 \mathrm{ppm}$ for the carbonyl groups, respectively. (see Table 2) The ${ }^{13} \mathrm{C}\left\{{ }^{1} \mathrm{H}\right\}$ NMR spectrum of 2 can be understood by 
having an overall $\mathrm{C}_{2 \mathrm{v}}$ symmetry for its solid-state structure. It is unclear of missing signals in the ${ }^{13} \mathrm{C}\left\{{ }^{1} \mathrm{H}\right\}$ NMR spectrum of $\mathbf{3}$, where it has been previously reported of missing apical ${ }^{13} \mathrm{C}$ signal in the ${ }^{13} \mathrm{C}\left\{{ }^{1} \mathrm{H}\right\}$ NMR spectrum of $\mathrm{Co}_{4}(\mathrm{CO}){ }_{12} \cdot{ }^{47}$

The ${ }^{207} \mathrm{~Pb}\left\{{ }^{1} \mathrm{H}\right\}$ NMR spectra of $\mathbf{1}$ and $\mathbf{3}$ displayed broad signals at $8007.2 \mathrm{ppm}$, and 9010.4 ppm ( Table 2) which are in fair agreement with ${ }^{207} \mathrm{~Pb}$ NMR signals observed for $\left(\eta^{5}-\mathrm{C}_{5} \mathrm{H}_{5}\right)(\mathrm{CO})_{3} \mathrm{M}-\mathrm{PbAr}{ }^{\mathrm{iPr} 6}(\mathrm{M}=\mathrm{Cr}, \mathrm{Mo}, \mathrm{W}), 9374-9659 \mathrm{ppm},{ }^{9}$ are also the chemical shift range for two-coordinated lead. ${ }^{44}$ Signal broadening in ${ }^{207} \mathrm{~Pb}\left\{{ }^{1} \mathrm{H}\right\}$ NMR spectrum of 3 could be caused by coupling to multiple ${ }^{59} \mathrm{Co}$ atoms as ${ }^{59} \mathrm{Co}$ is a $7 / 2$ spin nucleus and thus quadrupolar. ${ }^{48}$ The ${ }^{59} \mathrm{Co}\left\{{ }^{1} \mathrm{H}\right\}$ NMR spectrum of $\mathbf{3}$ displayed three signals at 173.0 ppm, -654.4 ppm, and -2016.0 ppm, respectively. The intensity ratio of the three signals is $1: 2: 1$ which corresponds to the three different chemical environments for the cobalt atoms seen in the crystal structure of $\mathbf{3}$. The chemical shifts in the ${ }^{59} \mathrm{Co}$ NMR spectrum of tetrahedral clusters supported by carbonyl ligands are generally unaffected by edge-bridging or face-bridging metals. ${ }^{48}$ The signal at $-173.0 \mathrm{ppm}$ can be assigned to $\operatorname{Co}(1)$, the more intense signal at $-654.4 \mathrm{ppm}$ can be assigned to both $\mathrm{Co}(2)$ and $\mathrm{Co}(3)$ where $\operatorname{Co}(1), \operatorname{Co}(2)$ and $\operatorname{Co}(3)$ are all bonded to two terminal carbonyl ligands in its solid state, and the signal at $-2016.0 \mathrm{ppm}$ to $\mathrm{Co}(4)$, which is bonded to two bridged carbonyl ligands and one terminal carbonyl ligand, respectively, suggesting that solidstate structure of $\mathbf{3}$ is also present in the solution structure. The chemical shifts of the signals are close to those chemical shifts reported for $\mathrm{Co}_{4}(\mathrm{CO})_{12},-668 \mathrm{ppm}$ (apical Co), and -2032 ppm (basal Co) in $\mathrm{CDCl}_{3}{ }^{48}$

The UV-vis spectra of 1 and 2 showed absorptions at $671 \mathrm{~nm}$ and $641 \mathrm{~nm}$ (Table 2), 
respectively, which are attributed to the $n-p$ transitions of the lead atoms as depicted in DFT calculations (Figure 4). These absorptions are close to the reported values for $\left(\eta^{5}\right.$ $\left.\mathrm{C}_{5} \mathrm{H}_{5}\right)(\mathrm{CO})_{3} \mathrm{M}-\mathrm{PbAr}{ }^{\mathrm{iPr} 6} 611-624 \mathrm{~nm} .{ }^{9}$ However, the UV-vis spectrum of $\mathbf{3}$ displayed an absorption at $368 \mathrm{~nm}$ that is blue-shifted compared to absorptions of plumbylenes, possibly due to the large extinction coefficient of cobalt-centered electronic transition where the absorption is very similar to what was reported for $\mathrm{Co}_{4}(\mathrm{CO})_{12}(372 \mathrm{~nm}) .{ }^{49}$

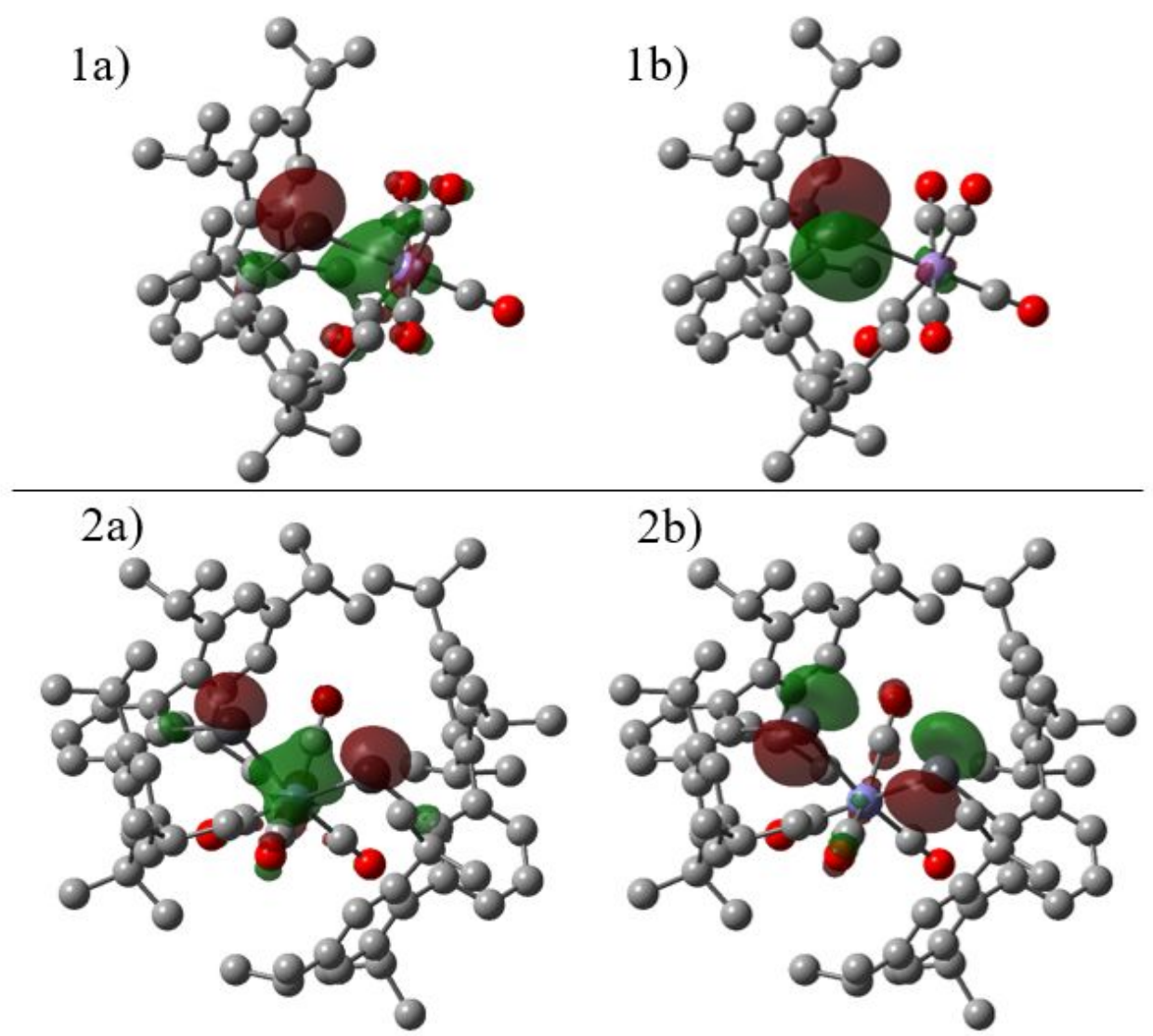

Figure 4. Depiction of calculated HOMO (1a) and LUMO (1b) of 1, calculated HOMO (2a) and LUMO (2b) of 2. HOMO-LUMO gap of 1 is calculated at $340 \mathrm{~kJ} / \mathrm{mol}$, and $325 \mathrm{~kJ} / \mathrm{mol}$ for 2 , hydrogens are omitted for clarity and the isovalue is set at 0.05 .

Compounds 1-3 were also characterized by IR spectroscopy. The IR spectrum of 1 
displayed a similar pattern to that of the corresponding complex, $\left(\mathrm{Ph}_{3} \mathrm{PAu}\right) \mathrm{Mn}(\mathrm{CO})_{5}$ (1961(vs) $\left.\mathrm{cm}^{-1}, 2062(\mathrm{~s}) \mathrm{cm}^{-1}\right) .{ }^{50}$ The IR spectrum of $\mathbf{1}$ showed two vibrational modes of the carbonyl groups, $\mathrm{A}_{1}\left(1958(\mathrm{~s}) \mathrm{cm}^{-1}\right)$, and $\mathrm{E}\left(2060(\mathrm{~m}) \mathrm{cm}^{-1}\right)$, which correspond to axial and equatorial $\mathrm{CO}$ stretching modes, respectively. The 4-band $\left(2 \mathrm{~A}_{1}+\mathrm{B}_{1}+\mathrm{B}_{2}\right)$ pattern in the IR spectrum of $\mathbf{2}$ is similar to what was reported for $(\mathrm{NHC}) \mathrm{Al}(\mathrm{Br})\left[\left(\mathrm{Fe}(\mathrm{CO})_{4}\right)^{51}(\mathrm{NHC}=\mathrm{N}\right.$-heterocyclic carbene $)$ and cis- $\mathrm{Fe}(\mathrm{CO})_{4}\left(\mathrm{SnR}_{3}\right)_{2}{ }^{52}$. CO stretching frequencies of 1 were calculated to be $1974 \mathrm{~cm}^{-1}$ for axial, $1975 \mathrm{~cm}^{-1}$ for equatorial, and $2055 \mathrm{~cm}^{-1}$ for axial + equatorial. CO stretching frequencies of 2 were calculated to be $1893 \mathrm{~cm}^{-1}, 1921 \mathrm{~cm}^{-1}, 1967 \mathrm{~cm}^{-1}$, and $2008 \mathrm{~cm}^{-1}$. The IR spectrum of 3 showed similarities with the calculated (BP86) vibrational frequencies of the theoretical

Table 2. Selected spectroscopic data for 1-3.

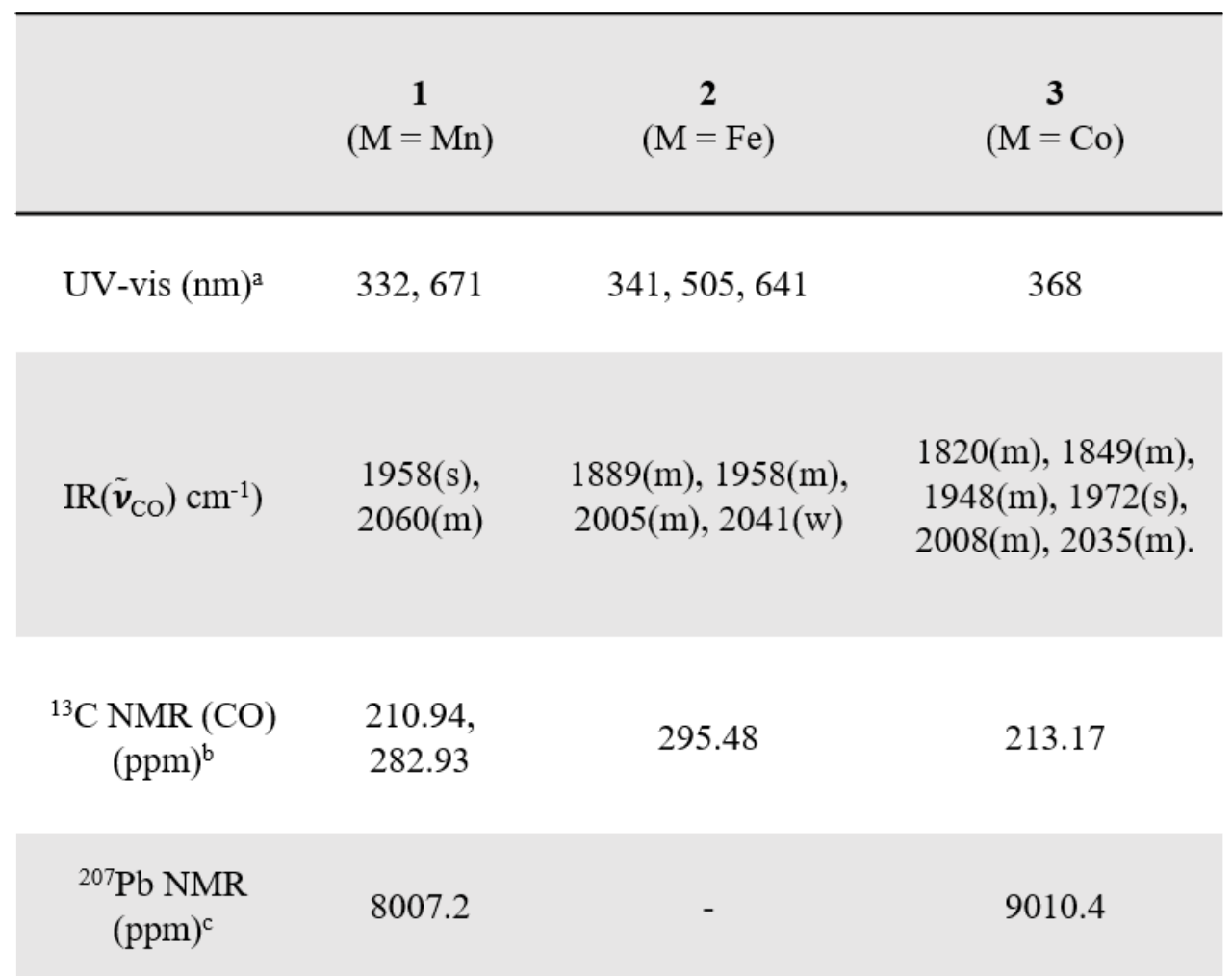

a. UV-vis spectra were collected in hexanes at 298K. b. ${ }^{13} \mathrm{C}\left\{{ }^{1} \mathrm{H}\right\}$ NMR spectra were 
collected in $\mathrm{C}_{6} \mathrm{D}_{6}$ at $298 \mathrm{~K}$. c. ${ }^{207} \mathrm{~Pb}\left\{{ }^{1} \mathrm{H}\right\}$ NMR spectra were collected in $\mathrm{C}_{6} \mathrm{D}_{6}$ at $298 \mathrm{~K}$. butterfly complex $\mathrm{Co}_{4}(\mathrm{CO})_{11}$, where the vibrational frequencies have relatively low wavenumber values of $1820 \mathrm{~cm}^{-1}$ and $1849 \mathrm{~cm}^{-1}$, which can be attributed to the bridging carbonyl groups, and that $2008(\mathrm{~m}) \mathrm{cm}^{-1}$ and $2035(\mathrm{~m}) \mathrm{cm}^{-1}$ to the terminal carbonyl $\operatorname{groups}(2020(\mathrm{~s}), 2026(\mathrm{~s}), 2032(\mathrm{~s})) .^{42}$

\section{Conclusion}

In conclusion, the syntheses and characterizations of complexes $\mathrm{Mn}(\mathrm{CO})_{5}\left(\mathrm{PbAr}^{\mathrm{iPr} 6}\right)(\mathbf{1})$, $\mathrm{Fe}(\mathrm{CO})_{4}\left(\mathrm{PbAr}^{\mathrm{iPr} 6}\right)_{2}(\mathbf{2}), \mathrm{Co}_{4}(\mathrm{CO})_{9}\left(\mathrm{PbAr}^{\mathrm{iPr} 6}\right)_{2}(\mathbf{3})$, have been described. They are rare examples of complexes synthesized by interaction of group 14 dimetallyne and dinuclear transition metal carbonyls. The reactivities of diplumbyne and dinuclear metal carbonyls can be attributed to the charge-shift bond character of $\mathrm{Pb} \equiv \mathrm{Pb}$ triple bond and M-M single bond. The syntheses of 1-3 are postulated to proceed via the reactions of $\mathrm{Ar}^{\mathrm{iPr} 6 \mathrm{~Pb}} \cdot$ radical fragment from the dissociation of $\mathrm{Ar}^{\mathrm{iPr} 6} \mathrm{PbPbAr}{ }^{\mathrm{iPr} 6}$ with $\mathrm{Mn}_{2}(\mathrm{CO})_{10}, \quad \mathrm{Fe}_{2}(\mathrm{CO})_{9}, \quad$ or $\mathrm{Co}_{2}(\mathrm{CO})_{8}$. Further studies of these synthesized metalloplumbylenes with small molecules are currently underway.

\section{ASSOCIATED CONTENT}

Supporting Information

The Supporting Information is available free of charge on the ACS Publications website at https://pubs.acs.org/doi/10.1021/acs.organomet.xxxxxxx.

Synthetic details for $\mathrm{Na}\left[\mathrm{Mn}(\mathrm{CO})_{5}\right]$, Computational details, NMR, IR and electronic spectra of the described compounds (PDF) 
Crystal data for CCDC 2018923 (CIF)

Crystal data for CCDC 2018925 (CIF)

Crystal data for CCDC 2027035 (CIF)

Optimized Cartesian coordinates (XYZ)

\section{Accession Codes}

CCDC 2018923, 2018925, 2027035 contain the supplementary crystallographic data for this paper. These data can be obtained free of charge via www.ccdc.cam.ac.uk/data_request/cif, or by emailing data_request@ccdc.cam.ac.uk, or by contacting The Cambridge Crystallographic Data Centre, 12 Union Road, Cambridge CB2 1EZ, UK; fax: +44 1223336033.

\section{AUTHOR INFORMATION}

\section{Corresponding Author}

Philip P. Power - Department of Chemistry, University of California, Davis, California 95616, United States; orcid.org/0000-0002-6262-3209; Email: pppower@ucdavis.edu

\section{Authors}

Qihao Zhu - Department of Chemistry, University of California, Davis, California 95616, United States; orcid.org/0000-0002-5566-4491

Petra Vasko - Department of Chemistry, Nanoscience Center, University of Jyväskylä, P.O. Box 35, FI-40014 University of Jyväskylä, Finland; orcid.org/0000-0003-4202-6869

James C. Fettinger - Department of Chemistry, University of California, Davis, California 95616, United States;

orcid.org/0000-0002-6428-4909

Notes

The authors declare no competing financial interest.

\section{ACKNOWLEDGMENTS}

We are grateful to the National Science Foundation (NSF) for financial support (Grants CHE-1565501) and for the dual-source X-ray diffractometer (Grant 0840444). PV 
would like to thank the Academy of Finland (project number 314794) and Prof. Heikki M. Tuononen for providing computational resources.

\section{References}

1. Fischer, E. O., On the Way to Carbene and Carbyne Complexes. Advances in Organometallic Chemistry, 14; Elsevier: Burlington, 1976; pp 1-32.

2. Marks, T. J., Dialkylgermylene- and -stannylene-pentacarbonylchromium complexes. J. Am. Chem. Soc. 1971, 93, 7090-7091.

3. Cotton, J. D.; Davison, P. J.; Goldberg, D. E.; Lappert, M. F.; Thomas, K. M., Co-ordination chemistry of heavy-atom group IV donors, and the crystal and molecular structure of $\left[\left(\mathrm{Me}_{3} \mathrm{Si}_{2}\right)_{2} \mathrm{CH}\right]_{2} \mathrm{SnCr}(\mathrm{CO})_{5}$. J. Chem. Soc., Chem. Commun. 1974, 893-895.

4. Petz, W., Transition-metal complexes with derivatives of divalent silicon, germanium, tin, and lead as ligands. Chem. Rev. 1986, 86, 1019-1047.

5. Hashimoto, H.; Tobita, H., Recent advances in the chemistry of transition metal-silicon/germanium triple-bonded complexes. Coord. Chem. Rev. 2018, 355, 362-379.

6. Álvarez-Rodríguez, L.; Cabeza, J. A.; García-Álvarez, P.; Polo, D., The transition-metal chemistry of amidinatosilylenes, -germylenes and -stannylenes. Coord. Chem. Rev. 2015, 300, 1-28.

7. Jutzi, P.; Leue, C., (Supermesityl)chlorogermylene (Supermesityl $=$ Mes* $=2,4,6-\mathrm{tBu}_{3} \mathrm{C}_{6} \mathrm{H}_{2}$ ): Synthesis and Derivatization to (Supermesityl)ferriogermylenes. Organometallics 1994, 13, 2898-2899.

8. Eichler, B. E.; Phillips, A. D.; Haubrich, S. T.; Mork, B. V.; Power, P. P., Synthesis, Structures, and Spectroscopy of the Metallostannylenes $\left(\eta^{5}-\mathrm{C}_{5} \mathrm{H}_{5}\right)(\mathrm{CO})_{3} \mathrm{M}-\mathrm{Sn}-\mathrm{C}_{6} \mathrm{H}_{3}-2,6-\mathrm{Ar}_{2}(\mathrm{M}=\mathrm{Cr}$, Mo, W; $\mathrm{Ar}$ $\left.=\mathrm{C}_{6} \mathrm{H}_{2}-2,4,6-\mathrm{Me}_{3}, \mathrm{C}_{6} \mathrm{H}_{2}-2,4,6-\mathrm{Pr}_{3}{ }_{3}\right)$. Organometallics 2002, 21, 5622-5627.

9. Pu, L.; Power, P. P.; Boltes, I.; Herbst-Irmer, R., Synthesis and Characterization of the Metalloplumbylenes $\left(\eta^{5}-\mathrm{C}_{5} \mathrm{H}_{5}\right)(\mathrm{CO})_{3} \mathrm{M}-\mathrm{Pb}-\mathrm{C}_{6} \mathrm{H}_{3}-2,6-\mathrm{Trip}_{2}\left(\mathrm{M}=\mathrm{Cr}\right.$, Mo, or W; Trip $\left.=-\mathrm{C}_{6} \mathrm{H}_{2}-2,4,6-\mathrm{i}-\mathrm{Pr}_{3}\right)$. Organometallics 2000, 19, 352-356.

10. Lei, H.; Guo, J.-D.; Fettinger, J. C.; Nagase, S.; Power, P. P., Synthesis, Characterization, and CO Elimination of Ferrio-Substituted Two-Coordinate Germylenes and Stannylenes. Organometallics 2011, 30, 6316-6322.

11. Simons, R. S.; Power, P. P., $\left(\eta^{5}-\mathrm{C}_{5} \mathrm{H}_{5}\right)(\mathrm{CO})_{2} \mathrm{MoGeC}_{6} \mathrm{H}_{3}-2$,6-- $\mathrm{Mes}_{2}$ : A Transition-Metal Germylyne Complex. J. Am. Chem. Soc. 1996, 118, 11966-11967.

12. Pu, L.; Twamley, B.; Haubrich, S. T.; Olmstead, M. M.; Mork, B. V.; Simons, R. S.; Power, P. P., Triple Bonding to Germanium: Characterization of the Transition Metal Germylynes $\left(\eta^{5}-\mathrm{C}_{5} \mathrm{H}_{5}\right)(\mathrm{CO})_{2} \mathrm{M}$ : Ge- $\mathrm{C}_{6} \mathrm{H}_{3}-2,6-\mathrm{Mes}_{2}\left(\mathrm{M}=\mathrm{Mo}, \mathrm{W}\right.$; Mes $\left.=-\mathrm{C}_{6} \mathrm{H}_{2}-2,4,6-\mathrm{Me}_{3}\right)$ and $\left(\eta^{5}-\mathrm{C}_{5} \mathrm{H}_{5}\right)(\mathrm{CO})_{2} \mathrm{M}: \mathrm{Ge}-\mathrm{C}_{6} \mathrm{H}_{3}-2,6-\operatorname{Trip}_{2}(\mathrm{M}$ $=\mathrm{Cr}$, Mo, W; Trip $\left.=-\mathrm{C}_{6} \mathrm{H}_{2}-2,4,6-\mathrm{i}-\mathrm{Pr}_{3}\right)$ and the Related Single Bonded Metallogermylenes $\left(\eta^{5}\right.$ $\left.\mathrm{C}_{5} \mathrm{H}_{5}\right)(\mathrm{CO})_{3} \mathrm{M}-\mathrm{Ge}-\mathrm{C}_{6} \mathrm{H}_{3}-2,6-\mathrm{Trip}_{2}(\mathrm{M}=\mathrm{Cr}, \mathrm{W})$. J. Am. Chem. Soc. 2000, 122, 650-656.

13. Filippou, A. C.; Philippopoulos, A. I.; Portius, P.; Neumann, D. U., Synthesis and Structure of the Germylyne Complexes trans- $\left[\mathrm{X}(\mathrm{dppe})_{2} \mathrm{~W} \equiv \mathrm{Ge}\left(\eta^{1}-\mathrm{Cp} *\right)\right](\mathrm{X}=\mathrm{Cl}, \mathrm{Br}, \mathrm{I})$ and Comparison of the $\mathrm{W} \equiv \mathrm{E}$ Bonds ( $\mathrm{E}=\mathrm{C}, \mathrm{Ge})$ by Density Functional Calculations. Angew. Chem. Int. Ed. 2000, 39, 2778-2781.

14. Filippou, A. C.; Portius, P.; Philippopoulos, A. I.; Rohde, H., Triple Bonding to Tin: Synthesis and Characterization of the Stannylyne Complex trans- $\left[\mathrm{Cl}\left(\mathrm{PMe}_{3}\right)_{4} \mathrm{~W} \equiv \mathrm{Sn}-\mathrm{C}_{6} \mathrm{H}_{3}-2,6-\mathrm{Mes}_{2}\right]$. Angew. Chem. Int. Ed. 2003, 42, 445-447.

15. Filippou, A. C.; Weidemann, N.; Schnakenburg, G.; Rohde, H.; Philippopoulos, A. I., Tungsten- 
Lead Triple Bonds: Syntheses, Structures, and Coordination Chemistry of the Plumbylidyne Complexes trans-[X $\left.\left(\mathrm{PMe}_{3}\right)_{4} \mathrm{~W} \equiv \mathrm{Pb}\left(2,6-\mathrm{Trip}_{2} \mathrm{C}_{6} \mathrm{H}_{3}\right)\right]$. Angew. Chem. Int. Ed. 2004, 43, 6512-6516.

16. Queen, J. D.; Phung, A. C.; Caputo, C. A.; Fettinger, J. C.; Power, P. P., Metathetical Exchange between Metal-Metal Triple Bonds. J. Am. Chem. Soc. 2020, 142, 2233-2237.

17. Stender, M.; Phillips, A. D.; Wright, R. J.; Power, P. P., Synthesis and Characterization of a Digermanium Analogue of an Alkyne. Angew. Chem. Int. Ed. 2002, 41, 1785-1787.

18. Phillips, A. D.; Wright, R. J.; Olmstead, M. M.; Power, P. P., Synthesis and Characterization of 2,6Dipp $_{2}-\mathrm{H}_{3} \mathrm{C}_{6} \mathrm{SnSnC}_{6} \mathrm{H}_{3}-2,6-\mathrm{Dipp}_{2}\left(\mathrm{Dipp}=\mathrm{C}_{6} \mathrm{H}_{3}-2,6-\mathrm{Pr}_{2}{ }_{2}\right)$ : A Tin Analogue of an Alkyne. J. Am. Chem. Soc. 2002, 124, 5930-5931.

19. Pu, L.; Twamley, B.; Power, P. P., Synthesis and Characterization of 2,6-Trip ${ }_{2} \mathrm{H}_{3} \mathrm{C}_{6} \mathrm{PbPbC}_{6} \mathrm{H}_{3}-2,6-$ Trip $_{2}$ (Trip $=\mathrm{C}_{6} \mathrm{H}_{2}-2,4,6-\mathrm{i}-\mathrm{Pr}_{3}$ ): A Stable Heavier Group 14 Element Analogue of an Alkyne. J. Am. Chem. Soc. 2000, 122, 3524-3525.

20. McCrea-Hendrick, M. L.; Caputo, C. A.; Linnera, J.; Vasko, P.; Weinstein, C. M.; Fettinger, J. C.; Tuononen, H. M.; Power, P. P., Cleavage of Ge-Ge and Sn-Sn Triple Bonds in Heavy Group 14 Element Alkyne Analogues $\left(\mathrm{EAr}^{\mathrm{iPr}}\right)_{2}\left(\mathrm{E}=\mathrm{Ge}, \mathrm{Sn} ; \mathrm{Ar}^{\mathrm{iPr}}{ }_{4}=\mathrm{C}_{6} \mathrm{H}_{3}-2,6\left(\mathrm{C}_{6} \mathrm{H}_{3}-2,6-\mathrm{Pr}_{2}\right)_{2}\right)$ by Reaction with Group 6 Carbonyls. Organometallics 2016, 35, 2759-2767.

21. Pangborn, A. B.; Giardello, M. A.; Grubbs, R. H.; Rosen, R. K.; Timmers, F. J., Safe and Convenient Procedure for Solvent Purification. Organometallics 1996, 15, 1518-1520.

22. Queen, J. D.; Bursch, M.; Seibert, J.; Maurer, L. R.; Ellis, B. D.; Fettinger, J. C.; Grimme, S.; Power, P. P., Isolation and Computational Studies of a Series of Terphenyl Substituted Diplumbynes with Ligand Dependent Lead-Lead Multiple-Bonding Character. J. Am. Chem. Soc. 2019, 141, 14370-14383.

23. King R. B., Stone F. G. A., Sodium Salts of Carbonyl Hydrides Prepared in Ethereal Media. In Inorg. Synth.; McGraw-Hill book: New-York, 1963; Vol. 7, pp 196-201.

24. Reimer, K. J., Shaver, A., Quick, M.H. and Angelici, R.J., Pentacarbonylmanganese Halides. In Inorg. Synth., Reagents for Transition Metal Complex and Organometallic Syntheses; WileyInterscience: Hoboken, 2006; pp 154-159.

25. Hicks, J.; Juckel, M.; Paparo, A.; Dange, D.; Jones, C., Multigram Syntheses of Magnesium(I) Compounds Using Alkali Metal Halide Supported Alkali Metals as Dispersible Reducing Agents. Organometallics 2018, 37, 4810-4813.

26. Lai, T. Y.; Tao, L.; Britt, R. D.; Power, P. P., Reversible Sn-Sn Triple Bond Dissociation in a Distannyne: Support for Charge-Shift Bonding Character. J. Am. Chem. Soc. 2019, 141, 12527-12530.

27. Joy, J.; Danovich, D.; Kaupp, M.; Shaik, S., Covalent vs Charge-Shift Nature of the Metal-Metal Bond in Transition Metal Complexes: A Unified Understanding. J. Am. Chem. Soc. 2020, 142, 12277 12287.

28. Goodman, J. L.; Peters, K. S.; Vaida, V., The determination of the manganese-manganese bond strength in $\mathrm{Mn}_{2}(\mathrm{CO})_{10}$ using pulsed time-resolved photoacoustic calorimetry. Organometallics 1986, 5, 815-816.

29. Pan, S.; Zhao, L.; Dias, H. V. R.; Frenking, G., Bonding in Binuclear Carbonyl Complexes $\mathrm{M}_{2}(\mathrm{CO})_{9}$ ( $\mathrm{M}=\mathrm{Fe}, \mathrm{Ru}, \mathrm{Os})$. Inorg. Chem. 2018, 57, 7780-7791.

30. Wolf, S.; Fenske, D.; Klopper, W.; Feldmann, C., $\left[\mathrm{Pb}\left\{\mathrm{Mn}(\mathrm{CO})_{5}\right\}_{3}\right]\left[\mathrm{AlCl}_{4}\right]$ : a lead-manganese carbonyl with $\mathrm{AlCl}_{4}$-linked $\mathrm{PbMn}_{3}$ clusters. Dalton Trans. 2019, 48, 4696-4701.

31. Braunschweig, H.; Damme, A.; Dewhurst, R. D.; Kramer, T.; Östreicher, S.; Radacki, K.; Vargas, A., Ditopic Ambiphilicity of an Anionic Dimetalloborylene Complex. J. Am. Chem. Soc. 2013, 135, 2313-2320. 
32. Clementi, E.; Raimondi, D. L.; Reinhardt, W. P., Atomic Screening Constants from SCF Functions. II. Atoms with 37 to 86 Electrons. J. Chem. Phys. 1967, 47, 1300-1307.

33. Pyykkö, P.; Atsumi, M., Molecular Single-Bond Covalent Radii for Elements 1-118. Chem. Eur. J. 2009, 15, 186-197.

34. Cordero, B.; Gómez, V.; Platero-Prats, A. E.; Revés, M.; Echeverría, J.; Cremades, E.; Barragán, F.; Alvarez, S., Covalent radii revisited. Dalton Trans. 2008, 2832-2838.

35. Herberhold, M.; Tröbs, V.; Milius, W.; Wrackmeyer, B., Carbonyliron-Lead Complexes: Multinuclear Magnetic Resonance Study in Solution and X-Ray Structure Determination of $\left[\mathrm{Et}_{2} \mathrm{PbFe}(\mathrm{CO})_{4}\right]_{2}$. Z. Naturforsch. B 1994, 49, 1781.

36. Wade, K., The structural significance of the number of skeletal bonding electron-pairs in carboranes, the higher boranes and borane anions, and various transition-metal carbonyl cluster compounds. J. Chem. Soc. D 1971, 792-793.

37. Mingos, D. M. P., A General Theory for Cluster and Ring Compounds of the Main Group and Transition Elements. Nat. Phys. 1972, 236, 99-102.

38. Wei, C. H., Structural analyses of tetracobalt dodecacarbonyl and tetrarhodium dodecacarbonyl. Crystallographic treatments of a disordered structure and a twinned composite. Inorg. Chem. 1969, 8, 2384-2397.

39. Plečnik, C. E.; Liu, S.; Chen, X.; Meyers, E. A.; Shore, S. G., Lanthanide-Transition-Metal Carbonyl Complexes: New $\left[\mathrm{Co}_{4}(\mathrm{CO})_{11}\right]^{2-}$ Clusters and Lanthanide(II) Isocarbonyl Polymeric Arrays. $J$. Am. Chem. Soc. 2004, 126, 204-213.

40. Chini, P., The closed metal carbonyl clusters. Inorg. Chim. Acta 1968, 2, 31-51.

41. Farrugia, L. J.; Braga, D.; Grepioni, F., A structural redetermination of $\mathrm{Co}_{4}(\mathrm{CO})_{12}$ : evidence for dynamic disorder and the pathway of metal atom migration in the crystalline phase. J. Organomet. Chem. 1999, 573, 60-66.

42. Zhang, X.; Li, Q.-s.; Xie, Y.; King, R. B.; Schaefer, H. F., A Carbonyl Group Bridging Four Metal Atoms in a Homoleptic Carbonylmetal Cluster: The Remarkable Case of $-\mathrm{Co}_{4}(\mathrm{CO})_{11}$. Eur. J. Inorg. Chem. 2008, 2158-2164.

43. Simons, R. S.; Pu, L.; Olmstead, M. M.; Power, P. P., Synthesis and Characterization of the Monomeric Diaryls $\mathrm{M}\left\{\mathrm{C}_{6} \mathrm{H}_{3}-2,6-\mathrm{Mes}_{2}\right\}_{2}\left(\mathrm{M}=\mathrm{Ge}\right.$, Sn, or $\left.\mathrm{Pb} ; \mathrm{Mes}=2,4,6-\mathrm{Me}_{3} \mathrm{C}_{6} \mathrm{H}_{2}-\right)$ and Dimeric Aryl-Metal Chlorides $\left[\mathrm{M}(\mathrm{Cl})\left\{\mathrm{C}_{6} \mathrm{H}_{3}-2,6-\mathrm{Mes}_{2}\right\}\right]_{2}(\mathrm{M}=$ Ge or Sn). Organometallics 1997, 16, 1920-1925.

44. Kano, N.; Tokitoh, N.; Okazaki, R., Synthesis and X-ray Crystal Structure of Bis $\{2,4,6$ tris[bis(trimethylsilyl)methyl]phenyl\}dibromoplumbane: The First Monomeric Diorganodihaloplumbane in the Crystalline State. Organometallics 1997, 16, 2748-2750.

45. McCrea-Hendrick, M.; Bursch, M.; Gullett, K.; Maurer, L.; Fettinger, J.; Grimme, S.; Power, P., Counterintuitive Interligand Angles in the Diaryls $\mathrm{E}\left\{\mathrm{C}_{6} \mathrm{H}_{3}-2,6-\left(\mathrm{C}_{6} \mathrm{H}_{2}-2,4,6-\mathrm{iPr}_{3}\right)_{2}\right\}_{2}(\mathrm{E}=\mathrm{Ge}, \mathrm{Sn}$, or $\mathrm{Pb})$ and Related Species: The Role of London Dispersion Forces. Organometallics 2018, 37.

46. Elschenbroich, C., Organometallic. Wiley-VCH: Weinheim, 2006; pp. 356-372.

47. Aime, S.; Gobetto, R.; Osella, D.; Milonej, L.; Hawkes, G. E.; Randall, E. W., Reinvestigation of the solution structure of $\mathrm{Co}_{4}(\mathrm{CO})_{12}$ by ${ }^{13} \mathrm{C}$ and ${ }^{59} \mathrm{Co}$ NMR. 2. J. Magn. Reson. (1969) 1985, 65, 308-315. 48. Richert, T.; Elbayed, K.; Raya, J.; Granger, P.; Braunstein, P.; Rosé, J., ${ }^{59}$ Co NMR in Tetrahedral Clusters. Magn. Reson. Chem. 1996, 34, 689-696.

49. Friedel, R. A.; Wender, I.; Shufler, S. L.; Sternberg, H. W., Spectra and Structures of Cobalt Carbonyls1. J. Am. Chem. Soc. 1955, 77, 3951-3958.

50. Coffey, C. E.; Lewis, J.; Nyholm, R. S., 339. Metal-metal bonds. Part I. Compounds of gold(0) 
with the carbonyls of manganese, iron, and cobalt. J. Chem. Soc. 1964, 1741-1749.

51. Tan, G.; Szilvási, T.; Inoue, S.; Blom, B.; Driess, M., An Elusive Hydridoaluminum(I) Complex for Facile $\mathrm{C}-\mathrm{H}$ and $\mathrm{C}-\mathrm{O}$ Bond Activation of Ethers and Access to Its Isolable Hydridogallium(I) Analogue: Syntheses, Structures, and Theoretical Studies. J. Am. Chem. Soc. 2014, 136, 9732-9742.

52. Pomeroy, R. K.; Vancea, L.; Calhoun, H. P.; Graham, W. A. G., Stereochemically nonrigid sixcoordinate metal carbonyl complexes. 3. The series cis- $\mathrm{Fe}(\mathrm{CO})_{4}\left(\mathrm{SnR}_{3}\right)_{2}(\mathrm{R}=$ methyl, ethyl, propyl, butyl, phenyl, chloro) and the x-ray structure of tetracarbonylbis(triphenylstannyl)iron(II). Inorg. Chem. 1977, 16, 1508-1514.

\section{For Table of Contents}

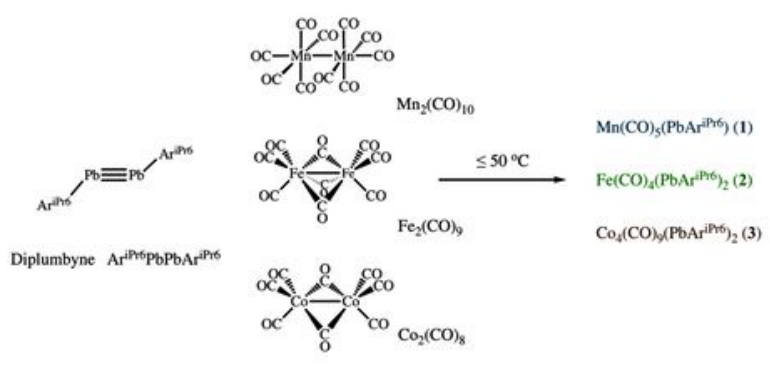

